\title{
Dwelling through multiple places: a case study of second home ownership in Ireland.
}

Bernadette Quinn

Technological University Dublin, bernadette.quinn@tudublin.ie

Follow this and additional works at: https://arrow.tudublin.ie/tfschhmtbook

Part of the Human Geography Commons

\section{Recommended Citation}

Quinn, B. (2004) Dwelling through multiple places: a case study of second home ownership in Ireland, pp. 45 - 59, in, Hall, C. M. and Muller, D. K., Tourism Mobility and Second Homes. Between Elite Landscapes and Common Ground, Channel View Publications, Clevedon, UK.

This Book Chapter is brought to you for free and open access by the School of Tourism \& Hospitality Management at ARROW@TU Dublin. It has been accepted for inclusion in Books / Book chapters by an authorized administrator of ARROW@TU Dublin. For more information, please contact arrow.admin@tudublin.ie, aisling.coyne@tudublin.ie, gerard.connolly@tudublin.ie. 
Dwelling through multiple places. A case study of second home ownership in Ireland

Dr. Bernadette Quinn

School of Hospitality Management and Tourism

Dublin Institute of Technology

Cathal Brugha St., Dublin 1.

Republic of Ireland.

Tel: 00-353-(0)1-4027557

Email: bernadette.quinn@dit.ie 


\section{Introduction}

The literature on second home ownership is by now quite extensive. While it may be also quite disparate, as Kaltenborn (1998) has claimed, identifiable areas within the general second home literature have begun to emerge. This paper focuses on one such area, that which explores the meaning of second home ownership. It re-visits one of the basic questions in the literature by asking why do people have second homes? This question has preoccupied several researchers over the last 20 years (e.g. Clout 1972, Jaakson 1986, Kaltenborn 1998, Chaplin 1999) and the ensuing literature has produced reasonably consistent findings by way of explaining the phenomenon. A number of explanatory motives have been put forward, most notably the desire to escape from routine, from home life, and ultimately from modernity itself. The second home is viewed as something of a release valve, providing a temporary escape that enables people to return to their routine lives having been revitalized and restored by their second home experiences. This chapter does not refute this basic theory but it argues that there is a need for further refinement of the processes and meanings at issues. In particular there is much scope for considering how the meaning that people attach to different places informs the decision to become involved in second home ownership. There seems little doubt that a desire to escape is a prevalent motive, but in terms of the places selected for escaping to, the process may not be as random as the literature has generally implied to date. The growing literature on what Clifford (1997:2) has termed 'dwelling-in-travelling' creates a useful context within which to explore how acquiring a second home creates a means of rediscovering and re-connecting with places that hold special meanings in peoples lives, thereby serving to counter the sense of place-alienation and dislocation associated with globalisation. This chapter furthers its case using empirical material from a case study of second home owners in south-east Ireland.

\section{Dwelling in multiple places}

In recent times, demand for second homes has risen significantly, fuelled by growing societal affluence, an increased prevalence of the aged within society, as well as by technological and transport advances and the economic restructuring associated with globalisation (Müller 2002). Within broader contexts, both tourism and otherwise, this 
increasing demand is of course, not unique. In terms of human mobility, there is now a growing awareness of how circulation between different places no longer represents an aberration from ordinary, settled life, but rather has become for many a normal part of contemporary lifestyles (Olwig 1997). 'Many people live and spend time in more than one place, moving between locales on a recurrent basis' (McHugh, Hogan and Happel 1995: 251). Urry (2000: 132) concurs, suggesting that 'contemporary forms of dwelling almost always involve diverse forms of mobility'. In tourism terms, globalisation has meant that places once considered to be exotic and far-flung have come within the reach of Western mass tourists. As Williams and Hall (2000) note, connections between places are increasingly international. Less dramatically, although no less significantly, they also continue to multiply within national contexts, where patterns of movements are characterised by increasing frequency. Contemporary tourism trends clearly show that travel for leisure purposes is becoming a more regular feature of lifestyle practices. There has been a major shift away from the historic pattern of taking one holiday annually, to a preference for taking multiple but shorter holidays each year. Thus, growing movement between primary and second homes is only one example of how mobility has become an increasingly normal part of contemporary living.

For some, increasing tourist mobility is interpreted as an indication of the deterritorialised spatiality of globalisation (Scholte 2000). This perspective finds resonance in the conceptualisation of post-modern tourists as individuals driven by a search for playful experiences (Cohen 1995), largely disinterested in the specifics of place or the authenticity of the experience being offered. Equally, it can be linked to interpretations of tourism as a practice that illustrates how contemporary social identities are increasingly formed through consumption and play, rather than through work or professional activities (Urry 1994). Yet, while there is increasing recognition that settled life in particular places is not necessarily a 'normal' state of being (Olwig and Hastrup 1997), increasing mobility need not necessarily be related to decreasing attachment to place. It is useful to remember that mobility has been recognized as a constitutive part of dwelling for a very long time. Tuan (1978: 14), for example, considered place to be 'a pause in movement'. While Clifford (1997: 2) introduced his ideas about 'dwelling-in-travel' by saying that 
'everyone's on the move, and has been for centuries'. Nevertheless, as Clifford (1997: 44) writes, once traveling is foregrounded as a cultural practice, then dwelling too, needs to be reconceived, (it is) no longer simply the ground from which traveling departs and to which it returns'. Thus basic understandings about 'home' are immediately problematised, as Harvey (1996: 246) and others have pointed out by asking 'who are we and what space/place do we belong?' In response, Williams and Kaltenborn (1999: 214) argue that home implies becoming native to a place, setting down roots and investing oneself in a place. Yet, how does this relate to contemporary assertions that we dwell in and through different places?

Massey's (1991) thoughts on a 'global sense of place' are useful in trying to conceptualise contemporary forms of dwelling, and contemporary place meanings. She calls for a recognition of the inter-connections, overlapping networks and change processes that shape and characterize all places, making them open and porous. More recently, Massey (2000: 231) has written about the 'multiplicity of histories' that make up the spatial, arguing that the histories of the places passed through permeate movement in space. These histories of place are further compounded by travelers' remembrances of times and practices associated with place and are re-worked continuously to re-new interactions and connections between places. Thus when McHugh (2000: 83) talks about people in the postmodern world having 'attachments and connections in multiple places', an obvious research task is to identify the nature of these linkages and to develop an understanding of they come to be formed. Is there an implication that people can feel themselves to be at home in more than one place at the same time? If this is the case, then how do people forge connections with different places? The literature on second homes has not really addressed this question to any real extent.

\section{Why have a second home?}

What it has done, is to pay significant attention to why people purchase second homes. A number of researchers have produced broadly consistent answers to this question. Clout (1972), for example, found that decisions were based on the need to escape temporarily from urban centers, as an investment, short-term enjoyment of leisure activities and 
possible retirement location. Jaakson (1986) in a detailed Canadian study reporting data gathered over a 20 year period identified and elaborated a number of key motives: routine and novelty, inversion, back-to nature, identity, surety, work, elitism, aspiration and time and distance. More recently, Chaplin (1999) in a study of British second home owners in France highlighted the escape motive, echoing Buller and Hoggart's (1994) broader argument that Britons look to France to find a rural way of living no longer available in the UK. Based on the literature, Kaltenborn (1998: 123) usefully derives a threefold category of motives classified as: identity management (contrast to modern everyday life, status symbol); recreation and mental/psychological 'maintenance' (contact with nature, social networks); and more pragmatic reasons (fits with life phase, children, etc., inexpensive holidays, capital investment). His own empirical work identified closeness to nature, a change from everyday life, physical and psychological rest, and being with the family as the most important motives (Kaltenborn 1998: 126)

Thus, while a multitude of motives have been advanced, it seems there is a broad consensus that 'escape from modernity'/ inversion of everyday life / return to nature seem to underpin people's involvement in second home ownership. As Kaltenborn (1998: 122) puts it, second home ownership could be a sign that people are seeking 'some grounding in a particular place that offers stability, a feeling of well-being and meaning in an otherwise demanding existence'. Chaplin (1999) supports this argument, positing the second home as a place where people can regain control over their lives, and escape from their routine situations where the demands of work and responsibilities can threaten to overwhelm. However, in much of the literature there is a sense that the totality of this 'escape' is not quite what it seems to be. Robertson (1977) first pointed to the irony of how "the owners of these so-called "places to get away from it all" often encounter a considerable amount of "it" when they arrive'. He was referring to the multitude of mundane tasks and responsibilities that go along with owning a second home. Jaakson (1986: 387) too, addresses this complication quite explicitly, both in referring to the routine inherent in repeatedly returning to a second home and to the work involved while there. Both, he explains, are acceptable to the second home owner because they are subsumed within the dominant purpose of the home, which is fundamentally 'leisure- 
oriented', in contrast to the dominant purpose of the principal dwelling which is workoriented. This discussion mirrors the broader tourism debate whereby the view that modern tourists seek out the exotic and the unfamiliar in order to escape routine and have themselves liminally renewed in the process (MacCannell 1989) is countered by the argument that they in reality take much of their everyday lives along with them (Urry 1990, Rojek 1995).

Jackson's idea that duality 'permeates everything in what it means to be a cottager: two places with two lives, providing inversion but also merging into symbiosis', deserves further investigation. Obviously, it is not possible to have a second home without already having a primary home. Economically, this is the case, but it is also true in broader motivational terms. After all, it is the routine associated with the primary home that acts as a 'push' factor, motivating the second home purchase. Yet as Robertson (1977) Chaplin (1999) and others have pointed out, the second home experience is also based on enjoying the familiar, the ordinary and the expected. Furthermore, as Jaakson points out, attitudes to both homes 'are influenced by awareness of the certainty of returning to the other' (1986: 389). Thus, the implication to be drawn is that life at the second home is an extension of life at the primary home. The former complements the latter. The 'escape' to the second home revitalises home life in the primary place. Williams and Kaltenborn (1999) neatly summarise the practice as both an escape from, and an extension of, modernity. It could be viewed as a modern solution, facilitated by increasing affluence and mobility, to a modern problem: the sense of placelessness and insecurity associated with time-space compression. As such, second home ownership is part of an adaptation to dwelling in modernity that relies on multiple belongings between two, or possibly more, places of residence.

Thus, second home ownership is one modern practice that illustrates how mobility inherently informs contemporary dwelling. Rather than being understood as a process that 'displaces' or deterritorialises humans, the increased mobility and circulation implicit in this practice re-affirms place rootedness, allowing individuals to consolidate attachments with multiple places. An issue that has not been specifically explored in the 
second home context, but one that it likely to apply, is Massey's (2000) general assertion that people's movement through space reflects a multiplicity of histories built up over time. Marshall and Foster (2002) have described migration as a process in time that relates to peoples' pasts and to their hoped for futures. It seems likely that second homes mobility patterns might illustrate a similar process. Certainly, a number of indications in the second home literature suggest that previous connections with places inform the second home location choices made by second home owners.

\section{Attachments in multiple places - how second homes fit in}

Understanding the place connections and mobility patterns associated with second home usage can be advanced using Roseman's (1992) general typology of cyclical migration. This considers temporary movements, ranging from weekly to seasonal and to infrequent circulation over the life course, and seeks to explain movement by reference to two sets of factors: production oriented factors (job and employment-related) and consumption oriented factors (family and amenity-related). Viewed within this framework, tourism as a form of mobility emerges as a consumption driven practice. Drawing on Roseman's typology, McHugh et al. (1995) graphically represent several examples of multiple residences associated with different stages of the life course. Some of these examples are consumption-oriented, and several are connected with tourist practices. They include holidaying in family second homes in childhood, staying with friends and relatives, owning second homes, re-locating to sunnier climes on a seasonal basis and sometimes ultimately retiring there. Roseman's typology is useful in pointing to the clear importance that tourist practices play in creating multiple place attachments over a life course. McHugh et al's (1995) use of the typology has developed our understanding of how connections with place evolve over time through tourist practices. They found, for example, that cyclical migration patterns in their Arizona study often occurred in stages, beginning with holidays and shorter visits in midlife and progressing towards extended winter residence upon full retirement.

While there has been no methodical analysis of cyclical migration specifically in the context of second homes, some researchers have indicated that similar patterns may exist. 
Burby, Donnely and Weiss (1972), for example, found 'friends and family' to be a key factor determining second home locations, while Nordin (1993) found family connections to be a common factor influencing location choice among Scandinavian second home owners. Other researchers have considered how second homes act as a forerunner to more permanent place connections. Swarbrooke (1992: S.35), for example, writing in the context of British owners of holiday homes in France, suggested that holiday homes could be bought with a view to using them as permanent residences at a later stage. A study undertaken by the Resort Municipality of Whistler (1995) in British Columbia, produced some empirical evidence in finding that $28 \%$ of holiday home owners intended retiring to live in the resort at some point in the future. More recently, Williams et al. (2001) noted that the purchase of a holiday home can act as a stepping stone to seasonal or permanent migration.

These findings, while tenuous, promote the idea that in buying second homes, peoples' desire to escape is both strongly tempered by an attempt to re-connect with experiences from their past and to strive for a continuity that will stretch into their futures. Memories of places associated with childhood, with family connections or with former holiday practices create a bank of memories that influence subsequent mobility patterns. Similar to the argument made in the section on why people buy second homes, the assertion here is that the escape in question is really an attempt to re-visit and rediscover experiences, times and places that create a sense of connectedness. Thus, second home ownership allows people to dwell in and through different places, enabling them to feel connected to more than one place at the same time. The remainder of this chapter discusses this assertion in the light of empirical findings from a case study of second home owners in south-east Ireland. It revisits the basic question of why do people have a second home and explores how they integrate their holiday home into their lifestyles. It then asks how people forge second home connections with particular places and whether the multiple places that come together to create meaning in peoples' lives are connected in some way. It begins by briefly describing the historical background to second home ownership in Ireland. 


\section{Levels of second home ownership in Ireland}

The international literature on second home ownership demonstrates that the phenomenon has long been a part of modern tourism practices in advanced Western societies. Some countries can point to very long histories of second home ownership. Kaltenborn (1998), for example, suggests that the phenomenon of the Norwegian cabin probably dates back $100-150$ years. In Scandinavia more generally, a long tradition of 'cottaging' is well recognised (Lofgren 1999, Müller 2001, Flognfeldt 2002). Müller (2001) for example, writes that in Sweden, legislation controlling the location of second homes in lake and seashore areas was introduced as early as 1974 in response to the phenomenon's increasing prevalence. Similarly, in France, the longevity of the phenomenon is indicated in the fact that the French population census has collected data on second home ownership since 1962 (Gallent and Tewdwr-Jones 2000). Certainly, in a majority of Western European countries, second home ownership had become an established practice in Europe by the 1970s (Gallent and Tewdwr-Jones 2000). Meanwhile, in a North American context, Jaakson (1986) has written about the long established incidence of second-home ownership in Canada and the historicallyembedded culture that centres on the Canadian 'cottage', the term universally used in Canada to refer to a holiday home. Since then, ownership levels everywhere have tended to show an upward trend. By the late 1980s, Go (1988) estimated that $35 \%$ of Italians owned a holiday home in their own country, the highest propensity of any European nationals to do so. Equivalent figures given for France and Switzerland at that time were $16 \%$ and $10 \%$ respectively.

The trends described above have little resonance in Ireland where, relative to the general European situation, significant levels of second home ownership is a recent phenomenon. Whereas Sweden could count half a million holiday homes (Löfgren 1999) by the 1970s, the practice of owning a second home and using it for leisure purposes was only then beginning to emerge in Ireland. Data compiled by Gallent and Tewdwr-Jones (2000: 66) show that among 17 Western European countries, Ireland had the lowest percentage of households owning second homes in 1970 and 1980, and the second lowest in 1988, at just 2\% for each of the given years. As Mottiar and Quinn (2003) have noted, levels of 
second home ownership in Ireland have their modest beginnings in the 1970s. Initially, holiday homes were detatched properties, overwhelmingly located in rural areas, with frequent locational clusters in coastal areas, relatively close to major urban areas (e.g. Wexford in the case of Dublin city, West Clare in the case of Limerick city). However, the extent of the phenomenon was relatively limited numerically and spatially.

The advent of the 'Celtic Tiger' economy and the economic prosperity witnessed in Ireland in the 1990s has changed this and there are signs now that levels of holiday home ownership are on the rise. Writing in an Irish context, Suiter (1999) has commented that 'the holiday home is no longer the preserve of the fortunate few. There's an increasing amount of cash in the economy and lots of it is finding its way into the booming holiday home market'. This development has been fuelled in part by a substantial increase in the second home housing stock. A tax incentive scheme introduced by the Irish Government in 1995 to revitalise outmoded traditional seaside resorts resulted in the building of 5,300 holiday cottages and apartments in 15 coastal locations around Ireland between 1995 2000. Clustered into group developments, the properties built under this scheme have been purchased either for personal holiday use or for renting as holiday accommodation.

The recentness of the second home ownership phenomenon in Ireland is easily explained relative to broader societal developments. Ireland is historically an agrarian society with one of the lowest populations densities in Europe (Central Statistics Office, 2002). Until relatively recently, it had low levels of urbanization and the push factors which underpin the 'desire for escape' identified in the literature were not major issues for Irish dwellers. In fact, in a European context, the Ireland of the 1970s and 1980s was for many continentals an attractive second home location, offering, as it did, arespite from modernity much sought after by European urban dwellers. During these decades Irish coastal towns and villages, particularly in southern and western counties like Cork and Clare witnessed sizeable numbers of continentals buying up properties for use as second homes. The rapid economic growth and societal changes experienced over the 1990s, however, created the conditions that promoted the growth of second home ownership among Irish people. On the one hand, factors including increasing affluence, increased 
leisure time and increased personal mobility have facilitated the phenomenon. Throughout the 1990s and into the early 2000s, GDP and consumer spending in the Republic of Ireland have grown faster than in most other European countries (Mintel 2002). This rising prosperity has been reflected in a multitude of ways. Car ownership levels, for example, have risen dramatically. Almost 161,000 new cars were registered in the Republic in 2001, a figure that was almost double that of 1990 (Central Statistics Office 2002). Outbound travel from Ireland also increased dramatically, growing at an average annual rate of $10 \%$ during the 1990s. Simultaneously, increasing urbanization, especially that occurring in the Dublin region, with its attendant problems of stressful living, commuting and traffic congestion, and a gradual detachment from historic rural connections have created a need for people to re-think how they want to live. For those with means, owning a second home is a way of restoring a degree of equilibrium to their lives.

Measuring what seems to be a growing phenomenon is not an easy task, however. Müller's (2002: 169) assertion that 'second homes are often covered in national property cadastres and thus well documented and easy to research' does not apply in the Irish case. Here, data pertaining to second home ownership for holiday purposes have only recently been gathered by the state's central statistics office. In fact, the first publication of these data is expected in Summer 2003. Bord Fáilte, the national tourism organization gathers data, however, the incidence of home ownership is thought to be under-reported by respondents, and the longitudinal data available is not comparable. Nevertheless, it would seem reasonably accurate to suggest that the role of second homes in accommodation bednights is at present modest but rising. Bord Fáilte figures suggest that they accounted for $3 \%$ of domestic bednights in 1988. Mintel (2002) figures for the 2001 season suggest that they are used by $6 \%$ of Irish holiday-makers. Certainly, the second home phenomenon has received increasing attention from the country's local authorities, which have become increasingly active in introducing planning regulations controlling the location of second homes regionally within Ireland. Much of this has been in response to the increased incidence of individuals building detached second homes on individual plots of land in rural, usually highly scenic areas. Kerry County Council, for example, 
considers that the county has experienced unsustainable pressure for holiday/second homes development in scenic area in recent years such that the visual and ecological quality of the landscape has experienced incremental deterioration (Kerry County Council Development Plan 2001). Since 1999 most of the local authorities in the coastal counties of Ireland (e.g. Kerry, Cork, Clare, Waterford, Donegal) have begun to treat second home development in their county development plans. Overwhelmingly, the trend is 'to generally not permit isolated houses for use as holiday homes or second homes' in areas under development pressure, in vulnerable areas or along scenic routes (County Clare Development Plan, 1999-2004). Clear distinctions are often made between local and external populations. For the former, restrictions can be relaxed, as in the case of the Cork Plan or, their position can be favoured, as in the case of the Donegal Plan, which seeks to provide 'incentives for local residents in areas subject to holiday home pressure' (County Donegal Development Plan 2000).

\section{Introduction to the study area and Methodology}

The study area in question here is North Wexford, an area located some 100 kilometres south of the capital city Dublin. North Wexford is a rural area, with the largest urban settlement in the area, Gorey, having a population of approximately 7,500. The south-east coastal county of Wexford has long functioned as a holiday destination for the Dublin market, drawing somewhere in the region of $50 \%$ of its domestic arrivals from Dublin each year. The Dublin region, itself, is the dominant source market for domestic tourists in Ireland, containing as it does, close to one third of the country's population of 3.9 million people Central Statistics Office (2002a). In an Irish context, it is well established as a second home location. Kinsella (1982) has written that the building of holiday bungalows (as second homes) dates back to the 1970s. With its scenic coastline and fine beaches, historic towns and a warmer and drier climate than elsewhere on the island, the area has obvious appeals. Its closeness to the greater Dublin urban area is clearly a key factor. As Halseth and Rosenberg (1995) note, the rural hinterland of cities have long been used by urban dwellers for recreational purposes, and second home ownership has been one of the most important forms of recreational land use in such areas. Müller 
(2002: 173) agrees, remarking that second homes are often located within the metropolitan areas' leisure peripheries, thereby allowing frequent visits.

Historically, caravans and mobile homes have been a prevalent accommodation option for Dubliners holidaying in Wexford, but in recent years there has been a marked increase in the rise of second home developments in the area. Reflecting the national trend, the stock of second homes in North Wexford increased considerably following the introduction of the tax incentive Seaside Resort Area Scheme introduced by the Irish government in 1995. The largest resort in North Wexford, Courtown, was designated under the scheme and this resulted in some 1,000 new houses being built for use as second homes or as rented accommodation for holiday-makers.

The data reported in this chapter are taken from a questionnaire survey administered to 76 second home owners in six small coastal villages/districts in North Wexford. The largest village is Courtown, a traditional seaside resort with a history of tourism dating back to the 1860s. Courtown has a year round population of 354 people (CSO, 1998) but in the summertime it is estimated that $3-4,000$ tourists stay in the resort (Webb, 2000). The other places, which include Ballymoney, Ballygarret/Cahore, Kilmuckridge, Blackwater and Curracloe, are more modestly, and much more recently associated with tourism activity. The data are drawn from a larger study that also surveyed tourist and local resident populations in the six areas. The surveys were administered in the summer of 2001 on a face-to-face basis, in public places in each of the six resorts. They comprised a mixture of open and closed questions, and a series of questions that asked respondents to rank particular statements in order of importance and to compare particular factors on a number of bases.

\section{Findings and Discussion}

\section{Profiling the second home owners}

The survey began by eliciting basic descriptive information from the second home owners. It found them to be overwhelmingly domestic in origin, with $50 \%$ coming from Dublin, and $20 \%$ from Wexford or adjacent counties. Just one respondent came from 
outside of Ireland (from the UK). This finding matches the broader tourism profile of the region as one dominated by domestic visits and having long established associations with the Dublin market.

A clear picture emerged in respect of age profile, with $67 \%$ being middle aged. Specifically, 35 - 44 year olds predominated at $40 \%$ of the sample, while a further $27 \%$ were aged $45-54$ years. At the outer ends of the spectrum, $16 \%$ were over 55 years and $14 \%$ were aged $25-34$ years. The dominance of the relatively youthful $35-44$ year age group may partly explain the fact that when broken down into gross household income levels, the majority of second home owners (40\%) earned mid-range incomes of between 24,000 and 40,600 euro.

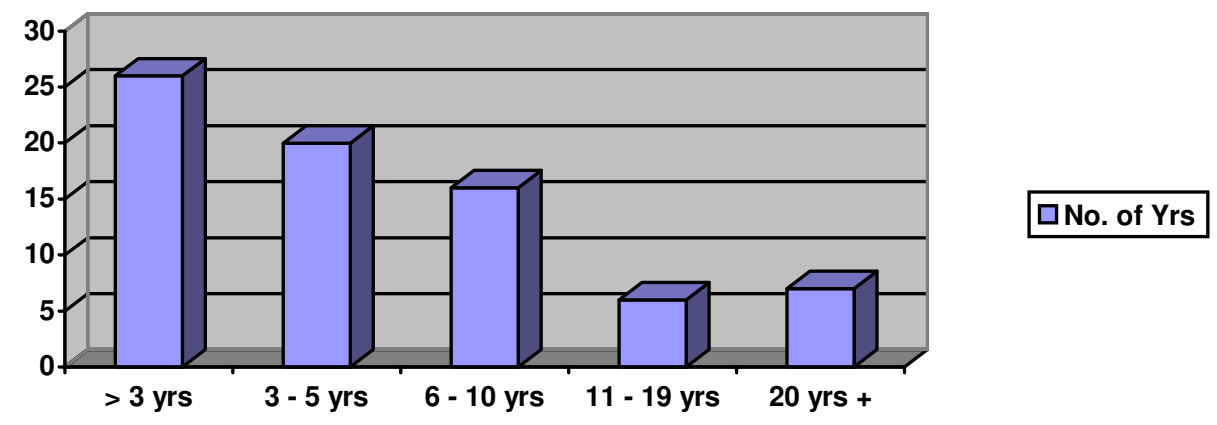

Figure 1: Length of time that the second home has been owned $(N=76)$

This most cursory analysis suggests that for the sample of second home owners surveyed, acquiring a second home was a moderate, rather than a life-changing lifestyle choice. They had chosen to connect with another place within easy reach of their primary residence, at a relatively early stage in life and at a time when their household incomes were relatively modest. For a majority of individuals, holiday home ownership was a recent phenomenon. Sixty per cent of the sample had owned their home for a period of less than 5 years. Just 17\% had owned their property for more than 11 years. The younger the age group, the more likely they were to have purchased in the previous five years. 


\section{Explaining the decision to buy a second home - escaping or returning?}

Two survey questions sought to explore why respondents had decided to buy a second home and why they had chosen the Wexford location in particular. Respondents were offered multiple reasons and asked to rank, in order of importance, which best explained their decisions. In response to the basic question about why they decided to buy a second home, it was clear that a desire to relax and to escape everyday routine prevailed. Twenty eight per cent of respondents ranked 'a place to relax' as their number 1 reason for making the purchase. The next most popular number 1 reason was 'a place to escape from everyday routine', cited by $18 \%$ of the sample. These findings are clearly in line with existing research findings.

Table 1: Most important reasons for purchasing a holiday home ( $N=76)$

\begin{tabular}{|l|l|l|}
\hline Reason & $\begin{array}{l}\text { Instances of being } \\
\text { ranked No.1 }\end{array}$ & $\begin{array}{l}\text { Instances of being } \\
\text { ranked in top 3 }\end{array}$ \\
\hline A place to relax & 21 & 40 \\
\hline A place to escape from everyday routine & 14 & 41 \\
\hline $\begin{array}{l}\text { A place to spend more quality time as a } \\
\text { family }\end{array}$ & 9 & 28 \\
\hline $\begin{array}{l}\text { Was a regular visitor and wanted to } \\
\text { own property here }\end{array}$ & 9 & 20 \\
\hline An investment & 9 & 16 \\
\hline To give the children more freedom & 6 & 34 \\
\hline Plan to retire to this area & 5 & 23 \\
\hline
\end{tabular}

These motives were further elaborated by the reasons respondents gave for choosing a particular location for their second home. Here there was an unambiguous preference to be close to the coast, or to be more specific, to the beach. The peacefulness and scenic quality of the area were also important factors. These findings are again in line with existing research, indicating the extent to which the second home location is prized for its recreational and amenity value. So too were the responses elicited from the question 
'what are the main differences between life here and life at your permanent residence?' The dominant response encompassed the relaxation / 'getting away from it all' theme, with having more family/child-oriented time, and spending more time with nature being secondary differences noted. These responses were supported by respondents' comments as to how the two homes differed. In this respect, dominant responses related to how life at the second home was more relaxing $(31 \%)$, more stress-free $(21 \%)$, was lived at a slower pace (14\%) and lent itself to spending more time outdoors (11\%).

Table 2: Reasons for choosing the particular Wexford location

\begin{tabular}{|l|l|l|}
\hline Reason & $\begin{array}{l}\text { \% Instances of being } \\
\text { ranked Number 1 }\end{array}$ & $\begin{array}{l}\text { \% Instances of being } \\
\text { ranked in top 3 }\end{array}$ \\
\hline Closeness to the beach & 41 & 60 \\
\hline The 'price was right' & 16 & 38 \\
\hline Used to holiday here as a child & 7 & 28 \\
\hline $\begin{array}{l}\text { Family/Friends with second home } \\
\text { in area }\end{array}$ & 9 & 20 \\
\hline Nearness to Dublin & 6 & 38 \\
\hline Peacefulness of area & 6 & 31 \\
\hline Scenic qualities & 5 & 34 \\
\hline Family connections in the area & 5 & 22 \\
\hline
\end{tabular}

However, while the desire to relax and to select a location that would enable relaxation occur predominated, the selection process was informed by individuals' affinities to place. For $58 \%$ of the sample, strong personal connections with the area had influenced their decision to buy a second home in Wexford. For 28\%, these connections extended historically to their childhood holidays, for $18 \%$, (excluding those who had already cited the childhood holiday association) it was a case of having been a regular visitor to the area and wanting to intensify this connection. A further $24 \%$ had an affinity with the area because of family connections, while $20 \%$ were influenced to purchase a house here because friends or family already had a second home in the area. Thus the decision was 
clearly not founded simply on general, 'placeless' factors like amenity value and a desire to relax. Neither was it a matter of simply 'escaping', because as the figures discussed here demonstrate, for a majority of the sample the second home represented a means of returning and of re-connecting with a place that already had special connotations for the individuals concerned.

Table 3: Previous connections to Wexford and the decision to purchase a second home

\begin{tabular}{|l|l|}
\hline Connection & \% Instances of being ranked in top 3 \\
\hline Used to holiday here as a child & 28 \\
\hline $\begin{array}{l}\text { Was a regular visitor and wanted to } \\
\text { own property here }\end{array}$ & 26 \\
\hline Family connections in the area & 24 \\
\hline $\begin{array}{l}\text { Family/Friends with second home } \\
\text { in area }\end{array}$ & 20 \\
\hline
\end{tabular}

\section{So, where is home?}

The data collected was abundantly clear on one point: these second home owners use their second homes with remarkable regularity. The circuitous movement between primary residence and North Wexford is for a majority of respondents a very regular occurrence that continues throughout the year. Geographical location promotes this extensive usage: all with the exception of 2 respondents resided within a radius of 100 kilometres of North Wexford. As Table 4 below illustrates, $70 \%$ of respondents used their second home on a year round basis, $20 \%$ of them claimed to use it 'intensively', meaning most weekends throughout the year, while a further $30 \%$ used it 'intensively' in summer and regularly throughout the year. This means that these second homes are being used both for short-stay weekend breaks and for longer-term holidays throughout the year at times that included Easter, Christmas, mid-term and of course, summer. 
Table 4: Frequency of usage of holiday home

\begin{tabular}{|l|l|}
\hline Frequency of usage & \% of respondents $(\mathbf{N}=68)$ \\
\hline Used intensively year round & 20 \\
\hline $\begin{array}{l}\text { Used intensively in summer and regularly } \\
\text { year round }\end{array}$ & 20 \\
\hline $\begin{array}{l}\text { Used intensively in summer and } \\
\text { occasionally year round }\end{array}$ & 30 \\
\hline Used intensively during summer months & 25 \\
\hline Used infrequently & 5 \\
\hline
\end{tabular}

The amount of time spent in the second homes under examination here attests to the wisdom of becoming a second home owner and deciding to live life between two homes. Using the motives identified in the literature, a question was devised to explore how respondents compared life in their two homes. As was to be expected, Jaakson's (1986) concept of the second home as a leisure-dominated sphere emerges unambiguously. As Table 5 below illustrates, overwhelming proportions of respondents feel more relaxed, have more leisure time, engage in more recreational pursuits, feel closer to nature, and think their children are more care-free while in their second home. Thus, the second home is clearly fulfilling the function that respondents intended. Smaller proportions, but still a majority of the sample, claimed they felt happier, spent more time with their family and led a healthier lifestyle in their second homes.

Yet, when asked 'where they felt most at home', a small majority (32\%) cited their primary home, while a larger percentage (41\%) said they felt unsure, or could not answer the question. One possible way of interpreting this response is to suggest that both places have a part to play in creating 'home'. Previous research (e.g. Chaplin, 1999) has suggested that second homes may rival the primacy of the 'primary' home in the role that they play in people's lives. Indeed, the findings reported here relating to the intensive usage of the second home could be interpreted as supporting this stance. However, the argument favoured here is that the second home phenomenon is not founded on competition between two places or two homes. Rather it involves developing multiple associations with places that contribute to a balanced, meaningful existence such that people can feel 'at home' in more than one place. This involves blending together 
elements from lives in both places, to form the sort of symbiosis that Jaakson (1986) referred to and to achieve the continuity that Williams and Kaltenborn (1999) argue is achieved through second home ownership.

Table 5: Life at the permanent residence and at the second home compared

\begin{tabular}{|l|l|l|l|}
\hline & $\begin{array}{l}\text { In permanent } \\
\text { residence (\%) }\end{array}$ & $\begin{array}{l}\text { In holiday home } \\
(\mathbf{\%})\end{array}$ & $\begin{array}{l}\text { Unsure / Not } \\
\text { applicable (\%) }\end{array}$ \\
\hline Feel more relaxed & 6 & 77 & 17 \\
\hline $\begin{array}{l}\text { Have more leisure } \\
\text { time }\end{array}$ & 3 & 90 & 7 \\
\hline $\begin{array}{l}\text { Spend more time } \\
\text { engaging in } \\
\text { recreational pursuits }\end{array}$ & 10 & 80 & 10 \\
\hline $\begin{array}{l}\text { Feel the children are } \\
\text { more carefree }\end{array}$ & 10 & 67 & 23 \\
\hline Feel more 'at home' & 32 & 27 & 41 \\
\hline $\begin{array}{l}\text { Spend more time } \\
\text { with family }\end{array}$ & 22 & 58 & 20 \\
\hline Feel closer to nature & 10 & 75 & 15 \\
\hline $\begin{array}{l}\text { Lead a healthier } \\
\text { lifestyle }\end{array}$ & 27 & 48 & 25 \\
\hline Feel happier & 14 & 49 & 17 \\
\hline
\end{tabular}

An insight into how this process unfolds is offered by analysing the social networks that encase the second home owners under investigation here. Respondents were asked to indicate with whom did they tend to socialize while in their second home. As Table 6 below illustrates, the largest percentage of respondents said that they socialized with the friends and relatives that they invited to come and stay with them in their second home. A further $45 \%$ said that they socialized with other second homes owners familiar to them from their lives at their permanent residences. These findings point to the stretching of social networks across space and represent a clear instance of how second home owners seek to integrate elements of familiarity, from their primary home life and from their historic store of personal connections with the area, into their second home lifestyle. As such, they are another example of how these holiday-makers are selective in the quality of the escape that they seek. In addition, a sizeable 52\% claimed to socialize with other second home owners whom they had first encountered in Wexford. This finding suggests an image of second home owners existing as a group of incomers functioning in 
something of an insular manner in the midst of a broader, locally embedded residential community. However, $46 \%$ of respondents indicated that they socialized with local Wexford residents. These findings capture the blend of the novel and the routine that characterizes second home life and again suggest that what is at issue here is not a simplistic escape from ' home' life, but an attempt to enrich lives by making connections between the multiple places that are meaningful in peoples' lives.

Table 6: Socialising while in second home

\begin{tabular}{|l|l|}
\hline Who do second home owners socialize with? & $\%$ \\
\hline $\begin{array}{l}\text { Other second home owners known from permanent residence } \\
\text { (e.g. Dublin) }\end{array}$ & 45 \\
\hline Friends/relatives invited to visit the second home & 62 \\
\hline Other second home owners first encountered in Wexford & 52 \\
\hline Local Wexford residents & 46 \\
\hline
\end{tabular}

\section{Conclusions}

As this chapter has discussed, the second home phenomenon raises fundamental questions about the nature of contemporary dwelling and about people's enduring need to seek out attachments to place. The findings that have emerged from the study reported here support existing research in identifying the second home as a leisure-oriented domain which offers a temporary release from the fast-paced, stressful and predominantly urban lifestyles that characterise contemporary western society. Unlike earlier research, this study stops short of using the word 'escape' to describe the practice, arguing that the concepts of return, rediscovery and renewal are equally apt at capturing the essence of what it is that second home owners are seeking to achieve. Far from being in search of the exotic, or even of difference, previous researchers have characterized second home owners as being strongly attached to the familiar and the routine. Thus, reflecting White's (1985) ideas about the ambivalence of migration and postmodernity, it is argued that the practice of living between two homes is characterized by a marked ambiguity. Second home ownership is a modern practice, devised by humans to counter the difficulties of modern living. 
Thus, as Urry (2000) argues there are a variety of dwellings, almost all of which involve complex relationships between belongingness and traveling. However, if 'people can indeed be said to dwell in various mobilities' (Urry, 2000: 157), the process of connecting with places en route is not random. It is made possible by 'a lifelong accumulation of experiences in place' (McHugh and Mings 1996) that people draw upon to make new, and to rediscover and reform, place connections. A key finding here is that second home mobility patterns can be strongly informed by previous connections to place. These may have been forged in a multitude of ways, through what Roseman (1992) termed production and consumption factors. In this case, the latter dominated, with personal factors focused on family connections, previous holiday experiences and social networks, influencing $58 \%$ of respondent's choice of second home location.

One finding that emerged quite strikingly here was the amount of time that the second home owners spent in their second home. Clearly, the findings are shaped by the fact that they relate to domestic second home mobility patterns. The North Wexford area offers what Muller (2002: 173) has termed 'comfortable accessibility' for the people in question and was thus heavily used as a weekend home. However, it was also widely used for longer holiday breaks throughout the year, suggesting that the second home can be deeply woven into people's ordinary lifestyles, complementing their life at the primary residence in an ongoing, undramatic way throughout the year. Furthermore, it may be that people are taking the decision to buy a second home more readily than in the past. Ragatz (1970) for example considered two factors were necessary for the purchase of a second home: time and money. Yet, among the sample surveyed here, neither were in abundance for a majority of the second home owners surveyed.

The usage of second homes in this way again supports the argument that mobility is implicit in contemporary dwelling. It prompts a questioning of the historically accepted notion that the practice of holidaying and the location of the holiday destination are clearly distinguishable from the rhythms, practices and places associated with home life. There has been a tendency to think of tourist flows as a relatively uncomplicated 
circuitous movement, where people move between two discrete places, their home and their holiday destination, in search of difference. Always, as Burkart and Medlik's (1991) widely accepted definition of tourism signaled, there was an intention to return home, to the place where the tourist was unambiguously understood to not only reside but also to belong. Certainly, there was definitional 'fuzziness' with respect to the duration of the travel involved and the variety of motivations in evidence, (Cooper et al. 1998) but tourist mobility historically did not tend to inspire major theoretical questions regarding notions of belonging nor did it query the primacy of the home place as the main source of place-based identity. The growing literature on second home ownership changes this.

These study findings cannot be generalized to a larger population and there is no intention to imply that they should be. This is an exploratory study into an issue that in an Irish context has received no attention to date, and this is something that needs redressing. Although second home ownership is as yet a minority practice in Ireland, both emerging indications and the experience of international trends suggest that it will rise. The second home mobility patterns discussed here represent domestic movements, but there are signs that rising levels of second home ownership are also informing the significant and consistent rise in outbound travel witnessed since the early 1990s. In broader cultural contexts, questions about mobility, place connections and belonging have informed a significant literature on Irish identity. Writers like Kearney (1997) have paid much attention to how mobility and connections with multiple places created largely through emigration processes have informed, and continue to shape, notions of Irish cultural identity. Recently, Nash's (2002) research on genealogical identities has shown the potential that exists for drawing on this literature to ask similar questions about contemporary tourism practices. Second home ownership represents another arena within which to usefully explore changing ideas of mobility, place connectedness and belonging, at a time when Irish society is rapidly becoming highly globalised. 


\section{References}

Buller, H. and Hoggart, K. (1994) International counterurbanization: British migrants in rural France, Avebury, Aldershort, UK.

Burkhart, A. J. and Medlik, S. (1991) Tourism, Past, Present and Future, Heinemann, UK.

Central Statistics Office (1998) Census of Population, CSO, Dublin.

Central Statistics Office (2002) Ireland North and South: A Statistical Profile, CSO, Dublin.

Central Statistics Office (2002a) Census of Population (Estimates), CSO, Dublin.

Chaplin, D. (1999) Consuming work/productive leisure: the consumption patterns of second home environments, Leisure Studies 18: 41-55.

Clare County Council (1999) County Clare Development Plan 1999-2004, Clare County Council, Ennis.

Clifford, J. (1997) Routes. Travel and Translation in the Late Twentieth Century, Harvard University Press, Cambridge, Massachusetts.

Clout, H. D. (1972) Second homes in the United States. Tijdschrift Voor Economishche En Sociale Geografie 63: 393-340.

Cohen, E. (1995) Contemporary tourism, trends and challenges. Sustainable authenticity or contrived post-modernity?, in R. Butler, D. Pearce (eds), Change in Tourism, People, Places, Processes, Routledge, London. 
Cooper, C., J. Fletcher, D. Gilbert, S. Wanhill (1998) Tourism. Principles and Practice, ( $2^{\text {nd }}$ ed.), Longman, Harlow, UK.

Donegal County Council (2000) County Donegal Development Plan, Donegal County Council, Lifford.

Flognfeldt, T. (2002) Second home ownership. A sustainable semi-migration, in C. M. Hall and A. M. Williams (eds), Tourism and Migration. New Relationships between Production and Consumption, Kluwer Academic Publishers, Dordrecht, pp. 187-203.

Gallent, N. and Tewdwr-Jones, M. (2000) Rural second homes in Europe. Examining Housing Supply and Planning Control, Ashgate publishers Ltd. UK.

Girard, T. C. and Gartner, W. C. (1993) Second home second view. Host community perception, Annals of Tourism Research 20: 685-700.

Go, F. (1988) Holiday Homes in Europe Travel and Tourism Analyst (3): 20-33.

Halseth, G. and Rosenberg, M. W. (1995) Cottagers in an urban field, Professional Geographer 47 (2): 148-159.

Harvey, D. (1996) Justice, Nature and the Geography of Difference, Blackwell, London.

Held, D. (1995) Democracy and the Global World Order, Polity Press, Cambridge.

Jaakson, R. (1986) Second home domestic tourism, Annals of Tourism Research 13: 367391.

Kaltenborn, B. P. (1997) Nature of place attachment: a study among recreation homeowners in Southern Norway. Leisure Sciences 19: 175-189. 
Kaltenborn, B. P. (1998) The alternate home - motives of recreation home use, Norsk Geografisk Tidsskrift 52: 121-134.

Kearney, R. (1997) Post-Nationalist Ireland: Politics, Culture, Philosophy, Routledge, London.

Kerry County Council (2001) Kerry County Development Plan, Kerry County Council, Tralee.

Kinsella, A. (1982) The Windswept Shore. A History of the Courtown District, Graphic Services, Dublin.

Löfgren, O. (1999) On Holiday: a History of Vacationing, University of Berkeley Press, Berkeley, Los Angeles.

Marshall, J. and Foster, N. (2002) "Between belonging": habitus and the migration experience, The Canadian Geographer 46 (1): 63-83.

Massey, D. (1991) A global sense of place, Marxism Today June 24-29.

Massey, D. (2000) Travelling thoughts, in P. Gilroy, L. Grossberg and A. McRobbie (eds), Without Guarantees: In Honour of Stuart Hall, Verso, London, pp. 225-232.

McHugh, K. E. (2000) Inside, outside, upside down, backward, forward, round and round: a case for ethnographic studies in migration, Progress in Human Geography 24 (1): 71-89.

McHugh, K. E.; Hogan, T. D. and Happel, S. K. (1995) Multiple residence and cyclical migration: a life course perspective, Professional Geographer 47 (3): 251-267. 
Mottiar, Z. and Quinn, B. (Forthcoming, 2003) Shaping leisure / tourism places - the role of holiday home owners: a case study of Courtown, Co. Wexford, Ireland, Leisure Studies.

Mintel (2002) Family Holidays - the Irish Market, Mintel International Group Ltd.

Müller, D. (2001) Second home tourism and sustainable development in North European peripheries. Paper presented at the TTRA European Chapter Annual Conference, Kiruna, Sweden, April 2001

Müller, D. (2002) German Second home development in Sweden, in C. M. Hall and A. M. Williams (eds), Tourism and Migration. New Relationships between Production and Consumption, Kluwer Academic Publishers, Dordrecht, pp. 169-186.

Nash, C. (2002) Genealogical Identities, Environment and Planning D: Society and Space 20: 27-52.

Nordin, U. (1993) Second Homes, in H. Aldskogius (ed.), Cultural Life, Recreation and Tourism. National Atlas of Sweden, Royal Swedish Academy of Science, Stockholm, pp. 72-79.

Olwig, K. F. (1997) Cultural sites: sustaining a home in a deterritorialized world, in K. F. Olwig and K. Halstrup (eds), Siting Culture: the Shifting Anthropological Object. Routledge, London, pp.15-32.

Olwig, K. F. and Hastrup, K. (1997) Introduction, in K. F. Olwig and K. Halstrup (eds), Siting Culture: the Shifting Anthropological Object. Routledge, London, pp.1-13.

Ragatz, R. L. (1970) Vacation housing: a missing component in urban and regional theory, Land Economics 46: 118-126. 
Resort Municipality of Whistler (1995) 1995 Community and Resort Monitoring Program, Planning Department, RMOW, Whistler.

Robertson, R. W. (1977) Second-home decisions: the Australian context, in J. T. Coppock (ed) Second Homes. Curse or Blessing? Pergamon Press, Oxford, pp. 119-138.

Rojek, C. (1995) Decentring Leisure: Rethinking Leisure Theory, Sage Publications, London.

Roseman, C. C. (1992) Cyclical and polygonal migration in a western context, in P. C. Jobes, W.F. Stinner and J. M Wardwell (eds) Community, Society and Migration, University Press of America, Lanham, MD, pp. 33-45.

Scholte, J. A. (2000) Global Civil Society, in N. Woods (ed), The Political Ewconomy of Globalization, Macmillan, London.

Suiter, J. (1999) Cash finds it way into holiday hideaways, The Irish Times, $24^{\text {th }}$ June.

Swarbrooke, J (1992) The impact of British visitors on rural France, Tourism in Europe: The 1992 Conference, Centre for Travel and Tourism, Newcastle upon Tyne, UK.

Tuan, Y-F. (1977) Space and Place: The Perspective of Experience, Minneapolis: University of Minnesota Press.

Urry, J. (1990) The Tourist Gaze, Sage Publications, London.

Urry, J. (1994) Cultural change and contemporary tourism, Leisure Studies 13: 233-238.

Urry, J. (2000) Sociology beyond societies. Mobilities for the Twenty First Century, Routledge, London.

Webb, C. (2000) Personal Interview. Chairman North Wexford Tourism. 
White, P. (1985) On the use of creative literature in migration study, Area, 17: 277-283.

Williams, A. and Hall, C. M. (2000) Tourism and migration: new relationships between production and consumption, Tourism Geographies 2: 5-27.

Williams, A. M., King, R., Warnes, T., Patterson, G., (2001) Tourism and international retirement migration: new forms of an old relationship in southern Europe. Tourism Geographies 2 (1): 28-49.

Williams, D. R. and Kaltenborn, B. P. (1999) Leisure places and modernity: the use and meaning of recreational cottages in Norway and the USA, in D. Crouch (ed), Leisure/Tourism Geographies. Practices and Geographical Knowledge, Routledge, London, pp.214-230. 